\title{
Milk, dairy food, calcium and fats: What does it happen before and after colorectal cancer development?
}

\author{
Daniela Barone ${ }^{1}$, Antonella Penon ${ }^{1}$, Antonio Giordano ${ }^{1,3}$, Letizia Cito ${ }^{2}$ \\ 1. Department of Medicine, Surgery and Neuroscience, University of Siena, Siena, Italy 2. Istituto Nazionale Per Lo Studio \\ E La Cura Dei Tumori “Fondazione Giovanni Pascale”, IRCCS, Italy. 3. Sbarro Institute for Cancer Research and Molecular \\ Medicine; Center for Biotechnology, College of Science and Technology, Temple University, Philadelphia, PA, USA
}

Correspondence: Letizia Cito. Address: via Ammiraglio Bianco, 83013, Mercogliano, Avellino, Italy.

Email: letizia.cito@cro-m.eu

Received: November 18, 2013 Accepted: December 10, 2013

DOI : $10.5430 /$ jst.v4n1p50

URL: http://dx.doi.org/10.5430/jst.v4n1p50

\section{Abstract}

The role of milk and dairy products in cancer prevention was debated for a long time. In some cases they seem to promote some hormones related neoplastic pathologies. Yet, as we here describe, milk and dairy products may be helpful in colorectal cancer prevention, because of their calcium content, showing the capability of inactivating bile acids. Fats seem not to be relevant. In fact, although animal fats generally exert a pro-neoplastic effects, recent findings demonstrated that milk and dairy foods preventive role of colorectal cancer is not affected by their fat content. IGF-1, which was similarly considered a pro-carcinogenic factor, was "exonerated" more than ten years ago, because different authors showed that its effects are not influential in people. Previous investigations led to consider IGF-1 as the principal cause of colorectal cancer, and it was just around the year 2000 that epidemiological studies refuted the pre-existing hypothesis about IGF-1. Hence, milk and dairy products may be advisable, not only because of their nutritional value, but also because of their preventive effect of colorectal cancer. Moreover, their consumption should be encouraged also in cancer patients, because their energy content, together with their micro- and macronutrients, may represent a good eating habit against cachexia. Yet, a special care should be taken with patients developing lactose intolerance and hypolactasia, a possible side effect of 5'FU chemotherapy. Finally, we have to stress that a further care should be taken about cheeses consumption. Their energy density and their saturated fatty acids content is not relevant in predisposing to colorectal cancer, but an excessive intake should be avoided not to develop either overweight/obesity, or hypercholesterolemia.

\section{Key words}

Milk, Calcium, Prevention, Colorectal cancer

\section{Introduction}

Colorectal cancer is one of the leading causes of cancer death in Western countries ${ }^{[1]}$. Familial adenomatous polyposis (FAP) and Lynch syndrome (hereditary non-polyposis colorectal cancer) are among the best known genetic conditions predisposing to colorectal cancer development ${ }^{[2]}$, whereas low intake of fresh fruits and vegetables, and meals rich in fats are considered key points of a predisposing diet ${ }^{[3,4]}$. Cappellani et al. ${ }^{[5]}$ recently analyzed various dietary elements and 
their role in colorectal cancer development, focusing their attention right on these perspectives. Moreover, Wada summarized efficaciously most of preventive diet related subjects, talking about foods "limited-suggestively" reducing colorectal cancer risk and foods "probably" reducing this risk ${ }^{[6]}$. In this last group, the author include cow's milk (hereafter mentioned simply as milk), dairy products and calcium, being the starting point for their key role in a both possible preventive role of colorectal cancer development, and possible chemotherapy supporting role for colorectal cancer patients. Whole milk and its derivatives are rich in calcium, which is able to bind bile acids and reducing their transforming potential ${ }^{[7]}$, but they also contain fats, whose oxidation products showed mutagenic effects ${ }^{[8]}$. Moreover, in $2001 \mathrm{Ma}$ et al. described the effects of milk as source of IGF-I (insulin-like growth factor 1) ${ }^{[9]}$, a mitogen and inhibitor of apoptosis ${ }^{[10]}$, whose effects are yet negligible among men with high IGF-I/IGFB-3 (Insulin-like growth factor-binding protein 3), in which calcium intake benefits exceed IGF-I intake possible risks ${ }^{[9]}$. Hence, although some published results may be not completely in favor of a frequent intake of milk and/or derivatives, summarizing all and more recent data available, it is reasonable asserting that this kind of food exerts a preventive role in colorectal cancer development. A recent, although not enough considered topic, is related to a supporting diet, after cancer development. In this review, we will focus our attention on the different role that milk and dairy products may exert in colorectal cancer prevention and in supporting management of oncologic patients.

\section{Calcium, fats and I GF-I : antagonist effects on colorectal cells in milk and dairy products}

Colorectal cancer development is a multistep process involving as before oncogenes activation, and later on tumor suppressors inactivation ${ }^{[1]}$. During various progressing stages, foods may cooperate with cell transformation, or fight against these events. Fresh fruits and vegetables are rich in fibers and antioxidants suggesting they can actually helping in colorectal cancer prevention. Colorectal neoplasms are highly affected by diet, both because the whole intestinal tract is dedicated to nutrients absorption and because patients are obviously particularly sensitive to nutritional status. Then, even more than in other neoplastic pathologies, prevention and supporting to chemotherapy may be performed by diet. Here we will summarize the effects of milk and dairy products consumption on colorectal cancer development. Their micro- and macronutrients give them an important role in diet of several countries. Yet, just because of their nutritional contents, they were considered pro-carcinogenic foods for a long time. We will consider the three principal bioactive compounds, referring to neoplasm development, showing that milk and its derivatives may be advisable in a healthy diet and may be considered preventive of colorectal cancer.

\subsection{GF-1}

Whole milk and, to a lesser extent, dairy products are largely advised for growing children because of their content in calcium, proteins and growth factors. Their fats content can be easily inserted in a healthy diet, if dairy products are consumed no more than twice a week and whole milk daily, according to age requirement. Their role in tumor development, either preventing, or triggering, has been analyzed for several years, probably because cancer continuous growing nature may be considered similar to a growing human being. IGF-I was considered for a long time among the main causes of colorectal cancer development. In 1989, Koenuma et al. showed the sensitivity of two colorectal cancer cell lines towards IGF-I, which induced an increase in cells duplication, regardless their different metastatic capability ${ }^{[12]}$, casting light on IGF-I mitogenic effect. Ten years later, Giovannucci published a review, highlighting the contribution of high IGF-I/IGFBP3 to various cancers development and focusing his attention also in direct and indirect antimitogenic role of IGFBP ${ }^{[13]}$. In the same year, Ma et al. stressed that high levels of circulating IGF-I, if compared to IGF-I/IGFBP3, may be a predisposing factor for colorectal cancer ${ }^{[14]}$. This hypothesis was commented by Burroughs et al. ${ }^{[15]}$, which wondered about a possible increased colorectal cancer risk in patients undergoing recombinant IGF-I therapies. Moreover, they pointed out the need of a deeper analysis, also about the possibility of actually reducing cancer risk by IGF-I/IGFBP3 adjustment. Probably, questions raised by Burroughs et al. were due to the idea that a ratio cannot be so sharp in predisposing to a neoplasm. Notwithstanding, they evaluated the analysis of Ma et al. as "the best epidemiological 
evidence" of that period and recognized that it represents a good hint for further studies. In 2001, Ma et al. finally published their analysis continuation, showing that contribution of IGF-I by milk and dairy products to increasing IGF-I plasma levels was negligible and not predisposing to colorectal cancer in men with high IGF-I/IGFBP3 ${ }^{[9]}$.

\subsection{Fats}

In 1984, Newmark et al. postulated that the adsorption of phosphate, calcium and dietary fats by food, may affect colorectal cancer development ${ }^{[16]}$. Actually, several publications described a possible connection between animal fats and colorectal neoplasms, as summarized by Vargas et al. ${ }^{[17]}$ and yet a well characterized link was not found, since all data collected are only suggestive ${ }^{[17,18]}$. Moreover, Sun et al. showed that milk fats may inhibit lung and colorectal cancer cell lines ${ }^{[19]}$. On the other hand, a very recent paper highlights not only the preventive role of milk and dairy products in colorectal cancer prevention, but also its independence from fats content ${ }^{[20]}$. Considering the broad number of participants, milk and dairy products can actually be considered preventive for colorectal cancer in European population. We believe that stressing race and geographical belonging of people involved in epidemiological studies is a topic of pivotal importance. Sarkar et al. analyzing patients of Eastern India, suffering from colorectal cancer, found that more than $40 \%$ belonged to low socio-cultural classes and were involved to heavy physical labor ${ }^{[21]}$. Hence, in spite of prevalence of colorectal cancer among obese and sedentary people, the occurrence of this neoplasm in skin and physical working people, suggests that other patterns of the tumor development are possible. Summarizing the various papers, it can be deduced that fat mass content in milk and its derivatives does not affect colorectal cancer development and it may even contribute to neoplasm prevention.

\subsection{Calcium}

Calcium content in milk is about $120 \mathrm{mg} / 100 \mathrm{ml}$ and according to Recommended Dietary Allowances (RDA) its daily intake should vary between $200 \mathrm{mg}$ for infants, to $1300 \mathrm{mg}$ for young women (independently from lactation). Then, it represents one of the most required micronutrient in human body, so as to be the most abundant macroelement. Calcium role in colorectal cancer prevention is due to its capability of binding bile acids and hence to reduce their proliferative effects ${ }^{[22]}$. More specifically, as Holt efficaciously wrote, "calcium may precipitate or bring out of solution fatty acids and bile acids that are potentially toxic to the colorectal epithelium" ${ }^{[18]}$. Furthermore, recent experiments performed in rats by Pierre et al., showed that calcium may normalize nitroso compounds and lipoperoxidation phenomena in rats fed with cured meat ${ }^{[23]}$. Biomarkers of these biochemical events were also measured in urine and feces of human volunteers, showing reduction when associated to adequate amount of calcium intake ${ }^{[23]}$. Again, Galas et al. performed a wide and careful hospital case-control study, analyzing more than 1500 patients, to whom they gave a questionnaire about life and diet habits ${ }^{[24]}$. The final results showed that the increase of calcium consumption effectively helps to prevent colorectal cancer development and the effect may be even enhanced by fibers intake. Hence a healthy diet, including a good amount of fibers whose protective action is well known ${ }^{[5]}$, may be improved with an adequate daily calcium intake. Park et al. showed that in order to gain a real colorectal cancer prevention, people should consume $1300 \mathrm{mg} / \mathrm{d}$ of calcium, whereas the increasing of this deal did not demonstrate improving effects ${ }^{[25]}$. Some authors published results slightly different, such as Aune et al. ${ }^{[26]}$. They performed a meta-analysis about the effects of milk, dairy products and cheese, from which they deduced that cheeses consumption, is not inversely correlated to colorectal cancer development ${ }^{[26]}$. Although the authors stressed the lack of evidence of cheese preventive effects, their results, in our opinion, should be considered a further support in encouraging milk and dairy products intake, with a special care in avoiding excessive cheese consumption. As extensively known, cheese is the dairy product with the higher calories content, hence not advisable for a daily consumption, in a healthy diet. Finally, we would like to mention the study performed by Rock, who effectively showed that calcium intake by food, rather by supplementation, is more effective in colorectal cancer prevention ${ }^{[27]}$.

We can conclude that due to their macro- and micronutrients, milk and dairy products may exert an effective role in colorectal cancer prevention. 


\section{Milk and dairy products in patients suffering from colorectal cancer}

Several authors investigated the effects of food in cancer prevention (Table 1), but so far, few papers can be found in scientific literature about diet as a support for chemotherapy in cancer patients. Cachexia and malnutrition are common side effects of patients undergoing antiblastic therapies and during the last decades, an evolution about hindering this kind of difficulties occurred. In 1976, Bozzetti et al. focused their attention on parenteral hyperalimentation, as a possible strategy to tackle cancer patients malnutrition ${ }^{[28]}$. In 2013, Berretta et al. highlighted the possibility of limiting cachexia of patients undergoing antiblastic therapy by diet ${ }^{[29]}$. Hence, during these years it has been affirming the idea that food may be helpful for people suffering from neoplastic pathologies. In this context, milk and dairy products surely represent a good source of energy and nutrients, useful for such a purpose. Moreover, experiments on colon and breast cancer murine models showed that milk fats can reduce gut damages induced by paclitaxel therapy ${ }^{[19]}$. Again, another murine colon cancer model demonstrated the efficacy of yoghurt in reducing the activity of beta-glucuronidase and nitroreductase, two procarcinogen enzymes ${ }^{[30]}$. Moreover kefir, a fermented milk drink, showed properties related to decreasing of sleep disturbance ${ }^{[31]}$. These results encourage milk and dairy products consumption during chemotherapy in colorectal cancer patients, whose gut is obviously particularly sensitive. Yet, it has to be highlighted the possibility of lactose intolerance and hypolactasia in patients treated with $5^{\prime} \mathrm{FU}{ }^{[32]}$. This side effect may be overcome avoiding lactose during chemotherapy and hence, only hard cheeses may be advisable, because of their total lack of lactose. In such a context, a nutritional scheme including hard cheeses consumption in colorectal cancer patients, may be highly advisable both to provide high energy density food and to avoid complaints caused by possible lactose intolerance. This diet adjustment should also take care of personal tastes and sensitivity of each single patient.

Table 1. Studies reporting the relationship between diet and colorectal cancer focusing on milk and dairy products

\begin{tabular}{|c|c|c|}
\hline Authors & Years & Main Results \\
\hline Ma J et al. & 2001 & $\begin{array}{l}\text { Intake of dairy products, characterized by low-fats, was associated with a modest increase in circulating } \\
\text { IGF-I levels, but lower risk of developing colorectal cancer. }\end{array}$ \\
\hline Sun X et al. & 2011 & $\begin{array}{l}\text { Milk and dairy products fats show anti-tumor, anti meta-static, and anti-angiogenic properties. They also } \\
\text { inhibit the side-effects of cytotoxic drugs. }\end{array}$ \\
\hline Murphy N et al. & 2013 & $\begin{array}{l}\text { The European Prospective Investigation into Cancer and Nutrition (EPIC) highlights the evidence for a } \\
\text { possible protective role of dairy products on colorectal cancer risk, independently by fats content. }\end{array}$ \\
\hline Aune D et al. & 2012 & Milk and dairy products, but not cheese, are associated with a reduction in colorectal cancer risk. \\
\hline Rock CL & 2011 & Milk intake is protective against colorectal cancer. \\
\hline Can G et al. & 2009 & Kefir decreases sleep disturbance in patients treated for colorectal cancer. \\
\hline Cappellani A et al. & 2013 & $\begin{array}{l}\text { Analysis of different dietary products and life style factors on colorectal cancer development to implement } \\
\text { preventive strategies. }\end{array}$ \\
\hline Berretta $\mathrm{M}$ et al. & 2013 & A good nutritional status in oncological patients during antiblastic therapy may be an effective support. \\
\hline Mason JB & 2002 & $\begin{array}{l}\text { Dietary habits and nutritional status, together with a high calories intake and overweight, play an important } \\
\text { role in determining the risk of developing colorectal cancer. }\end{array}$ \\
\hline Wada S. & 2012 & $\begin{array}{l}\text { Eating habits are the most important factor for colorectal cancer risk; cancer prevention is based on a } \\
\text { well-balanced diet and not on a single food based diet. }\end{array}$ \\
\hline Vargas AJ et al. & 2012 & $\begin{array}{l}\text { An energy- balanced diet rich in nutrient content from fruits, vegetables, nuts and grains, lean meats, } \\
\text { legumes, and low-fat dairy products is recommended to prevent colorectal cancer. }\end{array}$ \\
\hline
\end{tabular}

\section{Conclusions}

Milk and dairy products such as cheese, butter and yoghurt have been consumed ever since animals were domesticated. Their consumption is highly variable throughout the world, yet they represent an important diet segment in different countries. Their content of fats and proteins gives them high caloric density, hence their consumption should be set in a 
well scheduled diet. Moreover, milk and dairy products are also a source of retinol, riboflavin, and minerals such as calcium. So, they can be considered foods suitable for infants and children. Low-fat dairy products retain proteins, water-soluble vitamins, and minerals content whereas the fat-soluble vitamins are significantly reduced ${ }^{[18]}$. Various authors suggested that milk and dairy products were associated with reduced colorectal cancer risk, although anticarcinogenic role of fat content of milk is unclear. The EPIC study provided no evidence for divergent relationships for high and low-fat dairy products with colorectal cancer risk ${ }^{[20]}$. Moreover, Sun et al. demonstrated that milk may exert a sort of anti-metastatic effect during cancer chemotherapy ${ }^{[19]}$.

A possible explanation of colorectal cancer preventive role of milk and dairy products may be found in their calcium content. According to Lamprecht et al., calcium seems to exert pleiotropic effects on normal and preneoplastic colonic epithelial cells ${ }^{[33]}$, whereas the authors highlighted its efficacy in reducing bile acids ${ }^{[22]}$. Finally, it has to be considered that the high nutritional value of milk, may exert an important role in cachexia prevention in colorectal cancer patients, but also in synergizing with some chemotherapeutic strategies, taking care of cautions with should be taken in case of temporary lactose intolerance. Hence, milk and dairy foods may consumed with safety, paying attention to choose more or less seasoned, and more or less fat products, according to the each one health needs.

\section{References}

[1] Luu C, Arrington AK, Schoellhammer HF, Singh G, Kim J. Targeted therapies in colorectal cancer: surgical considerations. J Gastrointest Oncol. 2013; 4: 328-336. PMid:23997944

[2] Arends MJ. Pathways of colorectal carcinogenesis. Appl Immunohistochem Mol Morphol. 2013; 21: 97-102. PMid:23417071

[3] Watson AJ, Collins PD. Colon cancer: a civilization disorder. Dig Dis. 2011; 2: 222-228. PMid:21734388 http://dx.doi.org/10.1159/000323926

[4] Mason JB. Nutritional chemoprevention of colon cancer. Semin Gastrointest Dis. 2002; 13: 143-153. PMid:12230317

[5] Cappellani A, Zanghì A, Di Vita M, Cavallaro A, Piccolo G, Veroux P et al. Strong correlation between diet and development of colorectal cancer. Front Biosci. 2013; 18: 190-198. http://dx.doi.org/10.2741/4095

[6] Wada S. Colorectal cancer and preventive effects of food components. In Cancer Prevention - From Mechanisms to Translational Benefits. A. Georgakilas, ed. InTech, 2012; 207-230. http://dx.doi.org/10.5772/31433

[7] Aune D, Chan DS, Lau R, Vieira R, Greenwood DC, Kampman E et al. Dietary fibre, whole grains, and risk of colorectal cancer: systematic review and dose-response meta-analysis of prospective studies. BMJ. 2011; 343: d6617. PMid:22074852 http://dx.doi.org/10.1136/bmj.d6617

[8] Biasi F, Mascia C, Poli G. The contribution of animal fat oxidation products to colon carcinogenesis, through modulation of TGF-beta1 signaling. Carcinogenesis. 2008; 29: 890-894. PMid:18453540 http://dx.doi.org/10.1093/carcin/bgn106

[9] Ma J, Giovannucci E, Pollak M, Chan JM, Gaziano JM, Willett W et al. Milk intake, circulating levels of insulin-like growth factor-I, and risk of colorectal cancer in men. J Natl Cancer Inst. 2001; 93: 1330-1336. PMid:11535708 http://dx.doi.org/10.1093/jnci/93.17.1330

[10] Remacle-Bonnet MM, Garrouste FL, Heller S, André F, Marvaldi JL, Pommier GJ. Insulin-like growth factor-I protects colon cancer cells from death factor-induced apoptosis by potentiating tumor necrosis factor alpha-induced mitogen-activated protein kinase and nuclear factor kappaB signaling pathways. Cancer Res. 2000; 60: 2007-2017. PMid:10766192

[11] Yeatman TJ. Colon cancer. In Encyclopedia of life sciences. ed: Macmillan Publishers Ltd, Nature Publishing Group. 2001; 261-264.

[12] Koenuma M, Yamori T, Tsuruo T. Insulin and insulin-like growth factor 1 stimulate proliferation of metastatic variants of colon carcinoma 26. Jpn J Cancer Res. 1989; 80: 51-58. PMid:2540132 http://dx.doi.org/10.1111/j.1349-7006.1989.tb02244.x

[13] Giovannucci E. Insulin-like growth factor-I and binding protein-3 and risk of cancer. Horm Res. 1999; 51 Suppl 3: $34-41$. PMid:10592442 http://dx.doi.org/10.1159/000053160

[14] Ma J, Pollak MN, Giovannucci E, Chan JM, Tao Y, Hennekens CH et al. Prospective study of colorectal cancer risk in men and plasma levels of insulin-like growth factor (IGF)-I and IGF-binding protein-3. J Natl Cancer Inst. 1999; 91: 620-625. PMid:10203281 http://dx.doi.org/10.1093/jnci/91.7.620

[15] Burroughs KD, Dunn SE, Barrett JC, Taylor JA. Insulin-like growth factor-I: a key regulator of human cancer risk? J Natl Cancer Inst. 1999; 91: 579-581. PMid:10203270 http://dx.doi.org/10.1093/jnci/91.7.579 
[16] Newmark HL, Wargovich MJ, Bruce WR. Colon cancer and dietary fat, phosphate, and calcium: a hypothesis. J Natl Cancer Inst. 1984; 72: 1323-1325. PMid:6587152

[17] Vargas AJ, Thompson PA. Diet and nutrient factors in colorectal cancer risk. Nutr Clin Pract. 2012; 27: 613-623. PMid:22892274 http://dx.doi.org/10.1177/0884533612454885

[18] World Cancer Research Fund (WCRF)/American Institute for Cancer Research (AICR). Food, Nutrition, Physical Activity and the Prevention of Cancer: A Global Perspective. Washington, DC: AICR; 2007.

[19] Sun X, Zhang J, Gupta R, Macgibbon AK, Kuhn-Sherlock B, Krissansen GW. Dairy milk fat augments paclitaxel therapy to suppress tumour metastasis in mice, and protects against the side-effects of chemotherapy. Clin Exp Metastasis 2011;28:675-688. PMid:21739249 http://dx.doi.org/10.1007/s10585-011-9400-1

[20] Murphy N, Norat T, Ferrari P, Jenab M, Bueno-de-Mesquita B, Skeie G, et al. Consumption of Dairy Products and Colorectal Cancer in the European Prospective Investigation into Cancer and Nutrition (EPIC). PLoS One. 2013; 8: e72715. PMid:24023767 http://dx.doi.org/10.1371/journal.pone.0072715

[21] Sarkar S, Mukherjee R, Paira SK, Roy B, Banerjee S, Mukherjee SK. Profile of colorectal cancer in Eastern India. J Indian Med Assoc. 2012; 110: 901-903. PMid:23936955

[22] Pence BC, Dunn DM, Zhao C, Landers M, Wargovich MJ. Chemopreventive effects of calcium but not aspirin supplementation in cholic acid-promoted colon carcinogenesis: correlation with intermediate endpoints. Carcinogenesis. 1995; 16: 757-765. PMid:7728952 http://dx.doi.org/10.1093/carcin/16.4.757

[23] Pierre FH, Martin OC, Santarelli RL, Taché S, Naud N, Guéraud F, Audebert M, Dupuy J, Meunier N, Attaix D, Vendeuvre JL, Mirvish SS, Kuhnle GC, Cano N, Corpet DE. Calcium and $\alpha$-tocopherol suppress cured-meat promotion of chemically induced colon carcinogenesis in rats and reduce associated biomarkers in human volunteers. Am J Clin Nutr. 2013; 98: $1255-1262$. PMid:24025632 http://dx.doi.org/10.3945/ajcn.113.061069

[24] Galas A, Augustyniak M, Sochacka-Tatara E. Does dietary calcium interact with dietary fiber against colorectal cancer? A case-control study in Central Europe. Nutr J. 2013; 12: 134. PMid:24093824 http://dx.doi.org/10.1186/1475-2891-12-134

[25] Park Y, Leitzmann MF, Subar AF, Hollenbeck A, Schatzkin A. Dairy food, calcium, and risk of cancer in the NIH-AARP Diet and Health Study. Arch Intern Me. 2009; 169: 391-401. PMid:19237724 http://dx.doi.org/10.1001/archinternmed.2008.578

[26] Aune D, Lau R, Chan DS, Vieira R, Greenwood DC, Kampman E, Norat T. Dairy products and colorectal cancer risk: a systematic review and meta-analysis of cohort studies. Ann Oncol. 2012; 23: 37-45. PMid:21617020 http://dx.doi.org/10.1093/annonc/mdr269

[27] Rock CL. Milk and the risk and progression of cancer. Nestle Nutr Workshop Ser Pediatr Program. 2011; 67: $173-185$. PMid:21335998 http://dx.doi.org/10.1159/000325583

[28] Bozzetti F, Terno G, Pupa A, Uccellini M, Rota G, Emanuelli H. Parenteral hyperalimentation in patients with advanced neoplastic disease. Tumori. 1976; 62: 623-644. PMid:828982

[29] Berretta M, Michieli M, Di Francia R, Cappellani A, Rupolo M, Galvano F et al. Nutrition in oncologic patients during antiblastic treatment. Front Biosci. 2013; 18: 120-132. http://dx.doi.org/10.2741/4091

[30] de Moreno de LeBlanc A, Perdigón G. Reduction of beta-glucuronidase and nitroreductase activity by yoghurt in a murine colon cancer model. Biocell. 2005; 29: 15-24. PMid:15954463

[31] Can G, Topuz E, Derin D, Durna Z, Aydiner A. Effect of kefir on the quality of life of patients being treated for colorectal cancer. Oncol Nurs Forum. 2009; 36: E335-342. PMid:19887347 http://dx.doi.org/10.1188/09.ONF.E335-E342

[32] Osterlund P, Ruotsalainen T, Peuhkuri K, Korpela R, Ollus A, Ikonen M, Joensuu H, Elomaa I. Lactose intolerance associated with adjuvant 5-fluorouracil-based chemotherapy for colorectal cancer. Clin Gastroenterol Hepatol. 2004; 2: 696-703. http://dx.doi.org/10.1016/S1542-3565(04)00293-9

[33] Lamprecht SA, Lipkin M Cellular mechanisms of calcium and vitamin D in the inhibition of colorectal carcinogenesis. Ann N Y Acad Sci. 2001; 952: 73-87. PMid:11795445 http://dx.doi.org/10.1111/j.1749-6632.2001.tb02729.x 